Reprod. Nutr. Dévelop., 1983, 23 (4), 741-754.

\title{
Nitrogen and energy utilization in juvenile carp (Cyprinus carpio) fed casein, amino acids or a protein-free diet
}

\author{
S. J. KAUSHIK, K. DABROWSKI (*)
}

with the technical collaboration of Denise BLANC

Laboratoire de Nutrition et d'Elevage des Poissons, I.N.R.A., Saint-Pée-sur-Nivelle, 64310 Ascain, France.

$\left.{ }^{*}\right)$ Institute of /chthyobiology and Fisheries, Academy of Agriculture and Technology, Olsztyn-Kortowo, Poland.

Summary. Juvenile carp (Cyrpinus carpio) weighing $200 \mathrm{mg}$ were fed a diet containing either casein (CAS) or a mixture of synthetic amino acids (AA). Growth, digestibility of protein and amino acids, transit, postprandial nitrogen excretion and oxygen consumption were studied. Digestibility of protein and amino acids was very high with either diet. Compared to CAS-fed carp, AA-fed fish excreted much less ammonia, but showed loss of body nitrogen. To measure endogenous metabolism, two other groups were either fed a protein-free (PF) diet or were fasted. Fasted fish lost more weight and excreted more ammonia than PF-fed carp.

Metabolic fecal nitrogen amounted to $45 \mathrm{mg}$ of $\mathrm{N} .100 \mathrm{~g}$ of dry diet ${ }^{-1}$. Oxygen consumption rates were not affected by the dietary treatments, but the ratio of fat to protein utilized for energy purposes was much higher in PF and AA-fed carp than in CASfed or fasted carp.

\section{Introduction.}

In a previous attempt to study the different aspects of nitrogen and energy metabolism during the early life history of common carp, Cyprinus carpio, we followed changes occurring during early ontogenesis (Kaushik et al., 1982) and during the postabsorptive state in larvae and juveniles (Kaushik and Dabrowski, 1983). In the latter work, we compared fish fed a natural diet with those fed an artificial diet.

Carp larvae have been shown to sustain well solely on artificial diets after a preliminary adaptation period of exogenous feeding with live food (Bryant and Matty, 1981).

Different protein sources have been used in such artificial diets. The results are variable often due to the fact that not only feeding strategies and culture conditions are different but protein quality also varies. Studies in higher animals (Mitchell, 1924 ; Rérat, 1971) and in growing fish (Nose, 1971 ; Ogino and Chen, 1973) have demonstrated that various protein sources have different biological values in respect to maintenance and growth. 
The biological value of a protein reflects the ability of that protein to supply amino acids in the relative amounts required to form body tissues and maintain body functions. An ideal protein should thus be able to make available simultaneously the required amounts of the essential amino acids at the sites of utilization and for protein synthesis.

Attempts have been made to formulate diets using a mixture of synthetic amino acids reflecting the amino acid composition of a high quality, intact protein; these diets have been used as a source of nitrogen for nutritional studies in fish (Halver, 1957 ; Aoe et al., 1970 ; Kaushik, 1979). Compared to an intact protein diet, an amino acid diet resulted in poorer growth in many cases, especially in stomachless fish (Aoe et al., 1970 ; Nose et al., 1974 ; Mazid et al., 1978). The efficiency of the amino acid diet was improved to a certain extent by adjusting its $\mathrm{pH}$ (Nose et al., 1974 ; Wilson et al., 1977). These studies were all carried out on big fish.

The present study was initiated to compare the effect of either a protein diet (casein (CAS) or a synthetic amino acid (AA) diet of similar composition on the intermediate steps involved in nitrogen utilization in small juvenile carp. $A$ protein-free (PF) diet was also used to estimate metabolic fecal nitrogen (MFN) loss and endogenous nitrogen excretion (ENE). Studies on the digestibility of protein and energy in the diets, rates of food transit through the digestive tract, postprandial nitrogen excretion and oxygen consumption in carp were carried out.

\section{Materials and methods.}

a) Diets. - The composition of the three diets (AA, CAS and PF) used is given on table 1. The AA and CAS diets had different nitrogen sources. A mixture of synthetic amino acids (having a composition similar to that of casein) neutralized to $\mathrm{pH} 7.65$ with $\mathrm{NaOH}$ (Nose et al., 1974) was used in the AA diet ; vitamin-free casein (UBC, Cleveland, Ohio, ISA) was used in the CAS diet. The PF diet was virtually devoid of nitrogen. The formulations of the three diets were intended to be isocaloric. Two percent of chromic oxide $\left(\mathrm{Cr}_{2} \mathrm{O}_{3}\right)$ was included in all diets as an indicator for digestibility measurements. The different ingredients were mixed with water $(\simeq 20 \%$ ), blended in the laboratory and drawn into pellets that were dried in an air oven $\left(<40^{\circ} \mathrm{C}\right)$. The dried pellets, stored at $4{ }^{\circ} \mathrm{C}$, were crumbled and sieved according to the size of the young carp just before use.

b) Growth trials. - Twelve groups of 100 young carp (Cyprinus carpio) each (mean body weight (BW) : $210 \pm 10 \mathrm{mg}$ ) were alloted at random to square plastic containers (vol. : $3 \mathrm{I}$ ) with a constant flow of recirculated, temperature-controlled $\left(20 \pm 1{ }^{\circ} \mathrm{C}\right)$ water. Besides the three experimental groups fed the respective diets in triplicate, another triplicate batch was fasted. Fed fish received food to satiation hourly during the light hours $(8 \mathrm{a} . \mathrm{m}$. to $7 \mathrm{p.m}$.) on every day of the trial ; care was taken to avoid excessive distribution of food. Apart from the initial weighing, they were weighed weekly in lots and food distribution was noted. 
TABLE 1

Composition of the experimental diets $\left(\mathrm{g} \cdot \mathrm{kg}^{-1}\right)$

\begin{tabular}{|c|c|c|c|}
\hline \multirow{2}{*}{ Ingredients } & \multicolumn{3}{|c|}{ Diet } \\
\hline & $A A$ & CAS & PF \\
\hline Raw corn starch & 250 & 250 & 620 \\
\hline Cellulose & 60 & 60 & 70 \\
\hline Fish oil & 60 & 60 & 240 \\
\hline Soybean oil & 40 & 40 & - \\
\hline Vitamin mix ${ }^{(1)}$ & 20 & 20 & 20 \\
\hline Mineral mix ${ }^{(2)}$ & 20 & 20 & - \\
\hline Amino acid mix & 500 & - & - \\
\hline Casein (vitamin-free) & - & 500 & - \\
\hline Binder (Na-alginate) & 30 & 30 & 30 \\
\hline Chromic oxide & 20 & 20 & 20 \\
\hline \multicolumn{4}{|c|}{ Proximate composition (g. or $\mathrm{MJ} . \mathrm{kg}^{-1}$ ) } \\
\hline Dry matter & 897.5 & 909.8 & 905.8 \\
\hline Protein $(\mathrm{N} \times 6.25)$ & 423.4 & 454.2 & 7.0 \\
\hline Energy (MJ) & 20.0 & 21.7 & 21.9 \\
\hline $\mathrm{Cr}_{2} \mathrm{O}_{3}$ & 22.2 & 21.1 & 20.9 \\
\hline
\end{tabular}

(1) EIFAC, $1971 ;\left({ }^{2}\right)$ Luquet, $1971 ;\left({ }^{3}\right)$ Nose et al 1974.

c) Digestibility and transit. - Juvenile carp, varying in BW between 200 and $280 \mathrm{mg}$, were maintained in cylinderical jars with a conical bottom for rapid evacuation of feces that were collected over fine mesh $(50 \mu)$ cloth. The bottom of the tank, just above the conical constriction, was made of mesh screens that would allow evacuation of the feces but not of the fish. The carp were fed hourly with the experimental diets for several hours until satiation. The feces, collected over regular, short intervals $(30 \mathrm{~min})$ to avoid leaching of the nutrients, were pooled for digestibility measurements. Apparent digestibility of the diets and the dietary constituents as well as the true digestibility of the dietary constituents (protein and amino acids) were calculated using classical formaulae (Wilson et al., 1981).

The following procedure was used to estimate the rates of gut filling and evacuation. The fish were fed the marker-incorporated diets hourly for more than $12 \mathrm{~h}$ and were sampled at regular intervals $(30$ to $60 \mathrm{~min}$ ) during the period of gut filling. Feeding was then stopped, and we continued collecting fish samples hourly for more than $30 \mathrm{~h}$. The rates of filling and evacuation were calculated by following the amount of marker in the whole fish sampled at such intervals during and after feeding. At each sampling, fish BW was noted and marker concentration per unit of $\mathrm{BW}$ was used in calculating regressions.

d) Metabolism trials. - The metabolism chamber used for the measurement of nitrogen excretion and oxygen consumption rates and the methods of analyses have been described earlier (Kaushik et al., 1982; Kaushik and Dabrowski, 1983). Postprandial nitrogen excretion and oxygen consumption rates were measured simultaneously in triplicate in a group of carp fed one of the three 
experimental diets on days 1,7 and 14 of the feeding trial. Similarly, metabolic rates were also measured in triplicate at these intervals in a group of fasted carp. The model describing postprandial nitrogen execretion pattern (Kaushik and Dabrowski, 1983) could be applied to neither fasted carp nor those fed the PF diet.

e) Analytical methods. - Protein content $(\mathrm{N} \times 6.25)$ was measured after wet digestion (Kjeldahl) ; $\mathrm{Cr}_{2} \mathrm{O}_{3}$ content in the dry diet and feces and in whole fish was measured after perchloric acid digestion (Bolin et al., 1952) in a block digestor (Technicon BD 40) followed by automatic determination of bichromate in the digesta using diphenylcarbazide. Amino acid analyses of diets (dried in an oven, $110{ }^{\circ} \mathrm{C}, 24 \mathrm{~h}$ ) and freeze-dried fecal samples were made after acid hydrolysis $\left(6 \mathrm{~N} \mathrm{HCl}, 24 \mathrm{~h}, 120^{\circ} \mathrm{C}\right)$ and recovery in citrate buffers, by singlecolumn liquid chromatography (Technicon) following the classical methods of Moore et al. (1958). Statistical analyses were made using the methods of Snedecor and Cochran (1959).

\section{Results.}

a) Growth. - As seen from figure 1, the growth of CAS-fed carp, more rapid during the first week (specific growth rate (SGR) : $6 \% \mathrm{~d}^{-1}$ ), stabilized more or less during the second week (average SGR : $2 \% \mathrm{~d}^{-1}$ ). Feeding with AA resulted in practically no weight gain (SGR : - $0.1 \% . \mathrm{d}^{-1}$; body protein loss : $\left.0.35 \mathrm{mg} \cdot \mathrm{g}^{-1} \cdot \mathrm{d}^{-1}\right)$. The CAS-fed batch was the only one that showed positive $\mathrm{N}$-balance (body protein increment : $5.5 \mathrm{mg} \cdot \mathrm{g}^{-1} \cdot \mathrm{d}^{-1}$ ) with an apparent net protein utilization of $13 \%$ (table 2 ). Energy increment was also higher in CASfed carp compared to AA-fed fish. Fasted and PF-fed carp lost weight, and body protein loss was very high (2.7 and $2.0 \mathrm{mg} \cdot \mathrm{g}^{-1} \cdot \mathrm{d}^{-1}$, respectively).

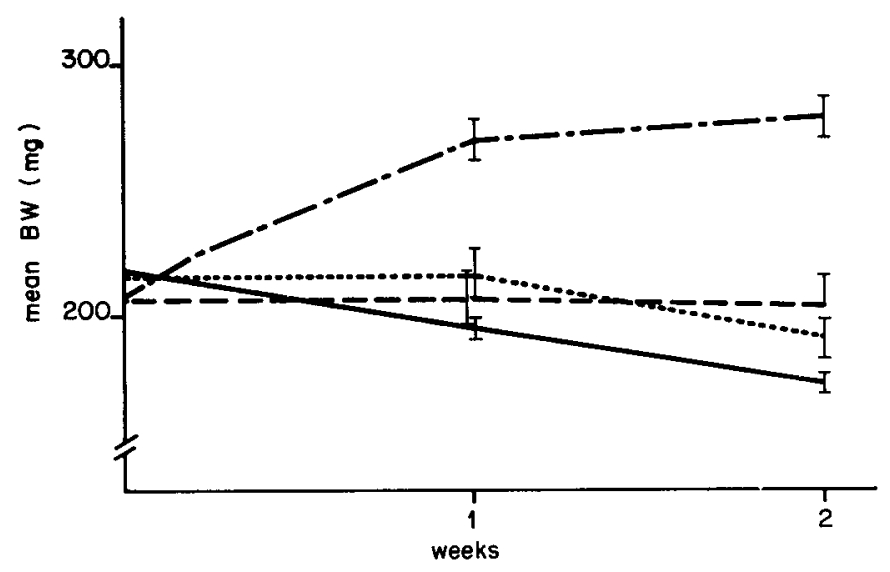

FIG. 1. - Growth of juvenile carp fed the CAS $(\bullet-\bullet)$, $A A(-1)$ or PF (-_- ) diet or fasted (-) 
b) Digestibility. - The digestibility of dry matter was above $70 \%$ for all diets (table 2); apparent protein digestibility was also high (>97\%). The PF diet contained very little nitrogen and the protein digestibility of this diet was also low $(13 \%)$. Metabolic fecal nitrogen (MFN) was calculated as $45 \mathrm{mg} \mathrm{N} .100 \mathrm{~g}$ dry

TABLE 2

Feed intake and growth performance of juvenile carp fed the experimental diets

\begin{tabular}{|c|c|c|c|c|}
\hline & FAST & $\mathrm{PF}$ & AA & CAS \\
\hline Initial BW (mg) & $\begin{array}{r}218.4 \pm \\
4.5\end{array}$ & $\begin{array}{c}215.3 \pm \\
10.4\end{array}$ & $\begin{array}{r}206.7 \pm \\
8.8\end{array}$ & $\begin{array}{r}209.6 \pm \\
6.9\end{array}$ \\
\hline Final BW (mg) & $\begin{array}{r}172.3 \pm \\
4.8\end{array}$ & $\begin{array}{r}190.3 \pm \\
8.1\end{array}$ & $\begin{array}{c}203.6 \pm \\
10.3\end{array}$ & $\begin{array}{r}277.6 \pm \\
8.5\end{array}$ \\
\hline Protein intake $\left(\mathrm{mg} \cdot \mathrm{g}^{-1} \mathrm{~d}^{-1}\right)$ & - & 0.8 & 41.0 & 42.2 \\
\hline Energy intake $\left(J \cdot g^{-1} d^{-1}\right)$ & - & 2486.0 & 1932.0 & 2011.0 \\
\hline $\begin{array}{l}\text { Protein increment } \\
\quad\left(\mathrm{mg} \cdot \mathrm{g}^{-1} \mathrm{~d}^{1}\right)\end{array}$ & -2.7 & -2.2 & -0.4 & +5.5 \\
\hline $\begin{array}{l}\text { Energy increment } \\
\left(\mathrm{J} \cdot \mathrm{g}^{-1} \mathrm{~d}^{-1}\right)\end{array}$ & -290.0 & 202.3 & 141.8 & 522.2 \\
\hline \multicolumn{5}{|l|}{ Digestibility (\%) } \\
\hline Dry matter & - & 73.6 & 81.0 & 78.9 \\
\hline Protein & - & 13.3 & 97.7 & 98.9 \\
\hline Protein(true) & - & - & 98.4 & 98.7 \\
\hline Energy & - & 83.8 & 83.7 & 83.1 \\
\hline
\end{tabular}

TABLE 3

Amino acid composition of the CAS and AA diets, apparent (AAAD) and true (TAAD) amino acid digestibility of these diets and metabolic fecal amino acid (MFAA) composition in juvenile carp fed a protein-free diet

\begin{tabular}{|c|c|c|c|c|c|c|c|}
\hline & \multicolumn{2}{|c|}{ Diets $\left({ }^{1}\right)$} & \multicolumn{2}{|c|}{$\operatorname{AAAD}(\%)$} & \multicolumn{2}{|c|}{ TAAD $(\%)$} & \multirow{2}{*}{ MFAA (2) } \\
\hline & CAS & $A A$ & CAS & $A A$ & CAS & $A A$ & \\
\hline Asp & 3.0 & 3.1 & 98.3 & 99.7 & 98.4 & 99.9 & 5.9 \\
\hline Thr & 1.8 & 2.5 & 98.5 & 99.3 & 98.9 & 99.8 & 12.7 \\
\hline Ser & 3.0 & 2.1 & 97.9 & 99.3 & 98.6 & 100.0 & 13.5 \\
\hline Glu & 10.9 & 5.8 & 98.6 & 99.7 & 99.0 & 100.0 & 18.5 \\
\hline Gly & 1.0 & 4.0 & 93.8 & 99.3 & 95.7 & 99.8 & 19.1 \\
\hline Ala & 1.4 & 2.8 & 96.1 & 99.4 & 97.2 & 99.7 & 9.7 \\
\hline Val & 2.8 & 3.0 & 98.5 & 99.5 & 98.8 & 99.9 & 9.6 \\
\hline Cys & 0.2 & 0.4 & 75.6 & 55.9 & 85.5 & 57.9 & 3.1 \\
\hline Met & 1.0 & 1.4 & 96.7 & 99.1 & 97.8 & 99.9 & 4.7 \\
\hline lle & 2.2 & 3.1 & 98.3 & 99.5 & 98.6 & 99.7 & 6.4 \\
\hline Leu & 4.9 & 4.8 & 98.3 & 99.6 & 98.6 & 99.9 & 16.1 \\
\hline Tyr & 2.8 & 3.6 & 98.6 & 98.5 & 98.8 & 98.9 & 6.4 \\
\hline Phe & 2.8 & 3.2 & 98.6 & 99.4 & 98.9 & 99.7 & 8.8 \\
\hline Lys & 4.2 & 3.2 & 98.7 & 99.3 & 99.2 & 100.0 & 22.6 \\
\hline His & 1.7 & 1.7 & 98.7 & 99.5 & 99.2 & 100.0 & 8.6 \\
\hline Arg & 2.1 & 3.6 & 97.6 & 99.5 & 98.5 & 100.0 & 17.8 \\
\hline
\end{tabular}

(1) As g. $100 \mathrm{~g}$ of dry diet ${ }^{-1} ;$ (2) As $\mathrm{mg} .100 \mathrm{~g}$ of dry diet $^{-1}$. 
$\operatorname{diet}^{-1}$. The true digestibility of protein from the CAS and AA diets was 98.7 and $98.4 \%$, respectively. The digestibile energy (DE) of the experimental diets was also very high (> $83 \%)$.

Apparent digestibilities of amino acids (ADAA) were more than $95 \%$ for most of the amino acids of the CAS and AA diets (table 3). True amino acid digestibilities (TDAA) of these diets were very high and even exceeded $100 \%$ for some amino acids. Total metabolic fecal amino acids (MFAA) amounted to $183 \mathrm{mg}$ AA. $100 \mathrm{~g}$ dry diet ${ }^{-1}$. Digestibility of cystine was comparatively lower than the ADAA for other amino acids, probably as a result of analytical problems. Basic amino acids (Arg, His and Lys) contributed more to total MFAA than other essential amino acids.

c) Gut filling and evacuation. - Both exponential and square root volumedependent models (Jobling, 1981) were tried; the former was found to give a better fit to the experimental data on tracer content in the gut during and after feeding. The rate coefficients, $b$, of the exponential model $1 S=A e^{b H}$, where $\mathrm{S}=\%$ of gut fullness, $A$ and $\mathrm{b}=$ coefficients and $\mathrm{H}=$ hours) estimated for each diet are given on table 4 . Both visual observations and the calculated $b$ values showed that juvenile carp voluntarily ate the $A A$ diet at a faster rate than they did the CAS or PF diet. However, this did not seem to affect the evacuation rate significantly. Although, the emptying rate in carp fed the AA diet was apparently higher $(7.5 \%$ per $h)$ than in those fed the CAS or PF diet, the rates were not significantly different $(p<0.01)$ from the calculated common slope of -0.069 . This evacuation rate was also related to meal size to the power of $0.262(r=0.984)$.

TABLE 4

Gut filling and evacuation rates in juvenile carp fed the experimental diets.

The coefficients of slope (b) in exponential models $\left(S=A e^{b H}\right)$ showing the relationship between $\%$ of gut fullness $(S)$ and time in hours $(H)$

\begin{tabular}{ccc}
\hline Diet & Filling rate (b) & Emptying rate $(-\mathrm{b})$ \\
\hline AA & $0.666^{\mathrm{a}}$ & $-0.075^{\mathrm{a}}$ \\
CAS & $0.427^{\mathrm{b}}$ & $-0.061^{\mathrm{b}}$ \\
PF & $0.633^{\mathrm{a}}$ & $-0.068^{\mathrm{a}}$ \\
\hline
\end{tabular}

Values with different superscripts are significantly different from each other $(p<0.01)$.

\section{d) Nitrogen excretion.}

Ammonia. - The postprandial patterns of ammonia excretion rates in carp fed CAS and AA are given on figures 2 and 3. The solid line connecting the points in these figures shows the fit obtained using the model described earlier. The different coefficients of the model are also given on table 5. Peak excretion rates were reached faster in carp fed AA than in those fed CAS. The coefficient, $\lambda_{3}$, of the model (table 5) is twofold higher in the former than in the latter. The decline $\left(\lambda_{4}\right)$ was equally rapid and basal rates were reached earlier (3-4 $\mathrm{h}$ after the 


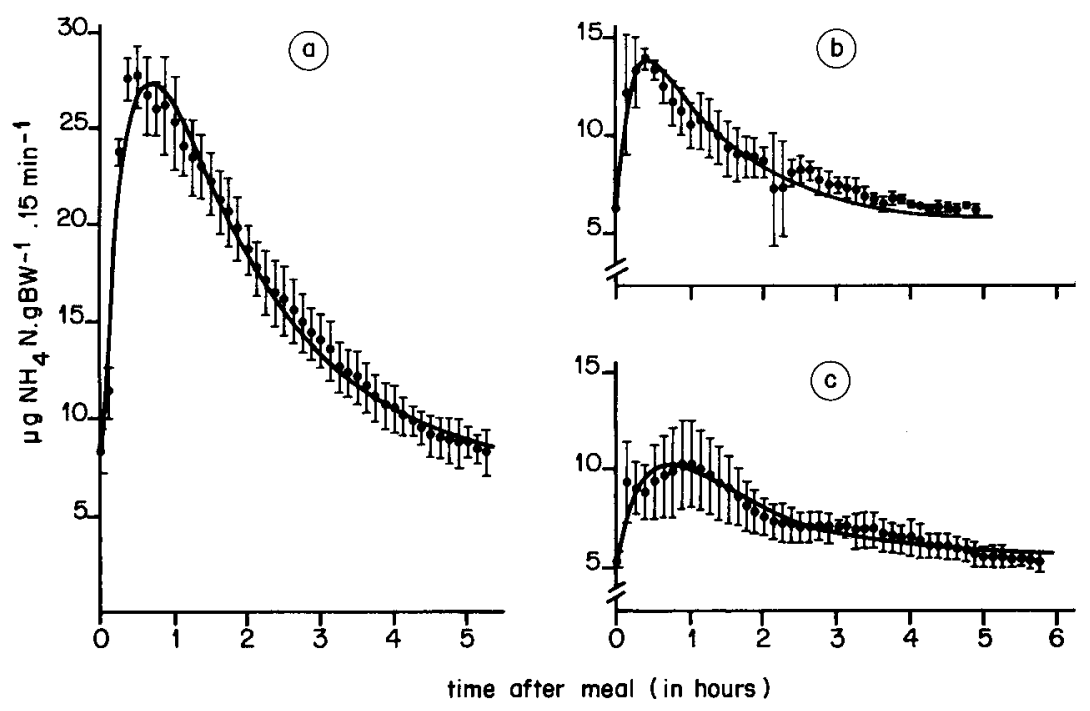

FIG. 2. - Postorandial ammonia excretion pattern in juvenile carp fed the CAS diet. The mean and the standard deviation of actual observations and the fit obtained with a model are given. The letters a, $\mathrm{b}$ and $\mathrm{c}$ correspond to patterns on days 1,7 and 14 , respectively.

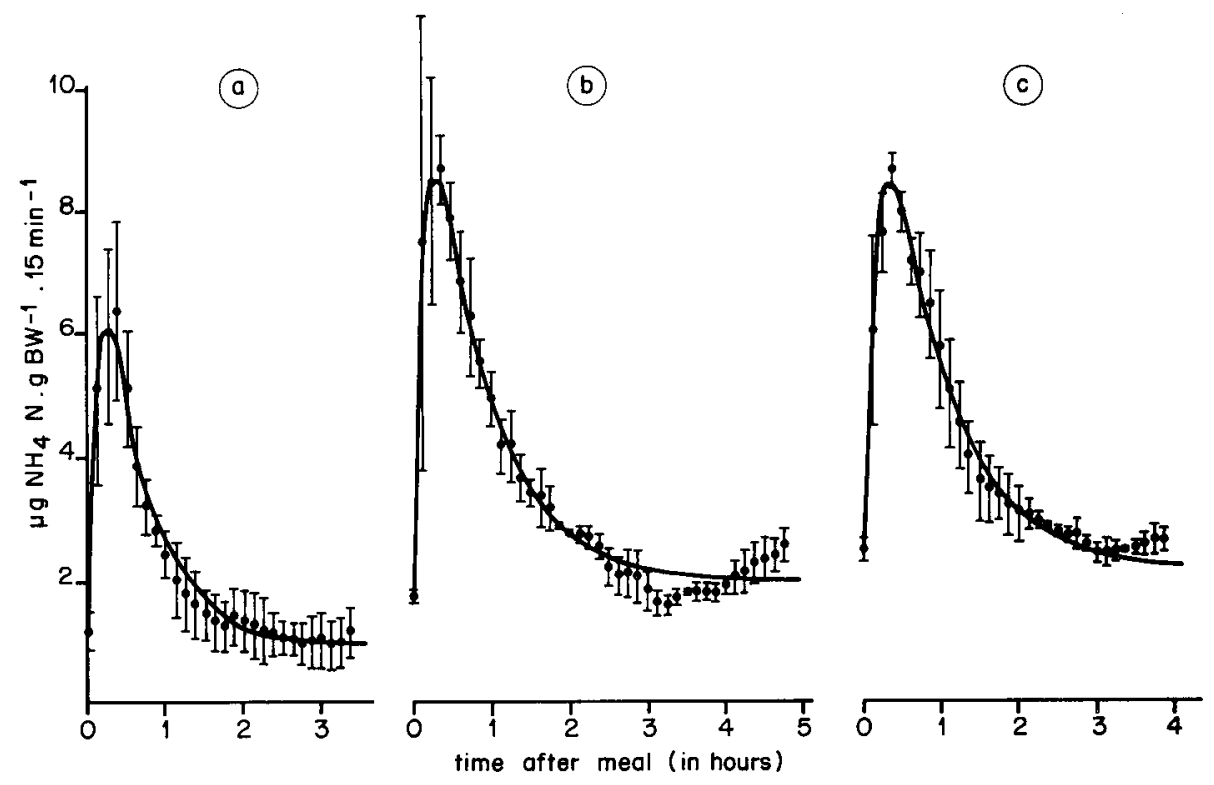

FIG. 3. - Postprandial ammonia excretion pattern in juvenile carp fed the AA diet. For details see legend of figure 2. 
TABLE 5

Coefficients of the model describing postprandial nitrogen excretion patterns in carp fed CAS and $\left.A A^{*}\right)$ diets

\begin{tabular}{cccccccc}
\hline Diet & Day & $\begin{array}{c}\text { N-intake } \\
\left(\mathrm{mg} \mathrm{N}^{-} \mathrm{g}^{-1)}\right.\end{array}$ & $\lambda 1$ & $\lambda 2$ & $\lambda 3$ & $\lambda 4$ & $\begin{array}{c}\text { Std } \\
\text { deviation } \\
\text { of fit }\end{array}$ \\
\hline CAS & 1 & 7.7 & 7.07 & 38.41 & 0.005 & 0.025 & 1.15 \\
& 7 & 6.8 & 5.45 & 12.50 & 0.006 & 0.055 & 0.65 \\
& 14 & 4.9 & 5.53 & 10.02 & 0.006 & 0.023 & 1.73 \\
AA & 1 & 4.4 & 1.10 & 9.00 & 0.014 & 0.080 & 0.35 \\
& 7 & 6.4 & 1.90 & 12.50 & 0.011 & 0.070 & 0.33 \\
& 14 & 5.4 & 2.18 & 11.94 & 0.011 & 0.052 & 0.30 \\
\hline
\end{tabular}

${ }^{*}$ ) Excretion rate $(R)=\lambda_{1}+\lambda_{2}\left(\exp \left(-\lambda_{3} T\right)-\exp \left(-\lambda_{4} T\right)\right)$, where $T$ represents time (see Kaushik and Dabrowski, 1983).

meal) in AA-fed than in CAS-fed fish (5-6 $\mathrm{h}$ after the meal). But both basal and peak excretion levels were significantly higher $(p<0.01)$ in carp fed the CAS diet than in those fed $A A$.

The ammonia excretion rate in CAS-fed carp was higher on the first day than later (fig. 2), and the hourly rates were higher than in fish fed AA (fig. 4). Similarly, on day 1 , fasted fish excreted nearly three times more ammonia $(25 \mu \mathrm{g}$ of $\left.N \cdot g^{-1} \cdot h^{-1}\right)$ than carp fed the PF diet $\left(7 \mu \mathrm{g}\right.$ of $\left.N \cdot g^{-1} \cdot h^{-1}\right)$. On day 14 , this level in PF-fed carp was even lower.

Urea. - Urea- $\mathrm{N}$ excretion rates after a meal did not follow any specific pattern and the mean hourly rates are shown on figure 4. Except for fish receiving the PF diet $\left(0.6-2 \mu \mathrm{g}\right.$ of $\left.\mathrm{N} \cdot \mathrm{g}^{-1} \cdot \mathrm{h}^{-1}\right)$, all the other groups excreted almost the same amount of urea (3-4 $\mu \mathrm{g}$ of $\left.N \cdot g^{-1} \cdot h^{-1}\right)$. But the amount of urea relative to total $\mathrm{N}$ excreted (ammonia + urea) was higher in the PF and AA-fed groups (>20\%) compared to fasted $(13 \%)$ or CAS-fed $(8 \%)$ fish.

Total daily endogenous nitrogen excretory (ENE) losses were thus greater ( $>700 \mu \mathrm{g}$ of $\mathrm{N} \cdot \mathrm{g}^{-1}$ ) under fasting than under non-protein nutrition $(240 \mu \mathrm{g}$ of $\mathrm{N} \cdot \mathrm{g}^{-1} \cdot \mathrm{d}^{-1}$ ). Average daily metabolic losses in the AA and CAS-fed groups were calculated as 6 and $17 \%$ of intake, respectively (table 6).

\section{TABLE 6}

Nitrogen utilization according to nitrogen source in juvenile carp. Mean values are expressed as $\mu \mathrm{g} \mathrm{N} \cdot \mathrm{g}^{-1} \mathrm{~d}^{-1}$

\begin{tabular}{lrr}
\hline N-source & AA & CAS \\
\hline Intake & 6560 & 6760 \\
Fecal loss & 200 & 140 \\
Metabolic loss (1) & 390 & 1150 \\
ENE (2) & 720 & 720 \\
Retention (3) & -60 & 890
\end{tabular}

(1) Ammonia + urea nitrogen ; ( $\left.{ }^{2}\right)$ Measured under fasting conditions ; ( $\left.{ }^{3}\right)$ Carcass analysis. 


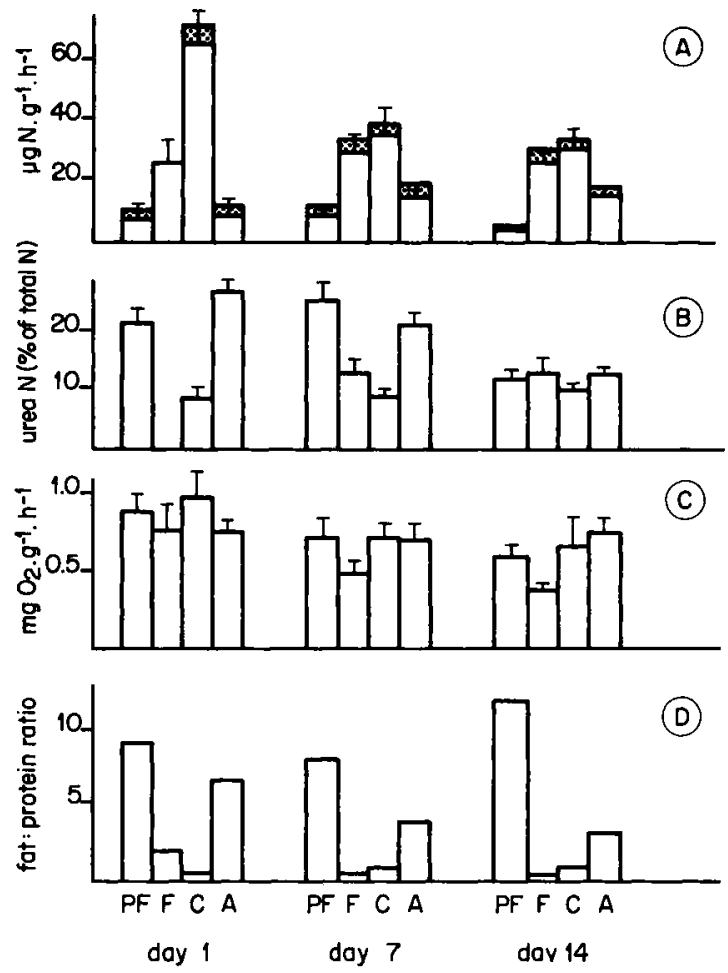

FIG. 4. - Nitrogen excretion (A) rate, proportion of urea excreted (B), oxygen consumption rate (C) and the fat-protein ratio utilized for energy purposes (D) in carp fed a protein-free (PF), casein $(\mathrm{C})$ or amino acid (A) diet or fasted (F). The dotted and white portions in A represent the rates of urea and ammonia excretion, respectively.

We computed metabolizable energy (ME) values from data on metabolic nitrogen losses, using values for the heats of combustion of nitrogenous end products (Elliott and Davison, 1975). ME expressed as a percentage of DE was very high (>95\%) and did not differ among the diets. On the contrary, energy retention was better with the CAS than with the AA or PF diet (table 2).

e) Oxygen consumption and energy utilization. - The oxygen consumption rates increased immediately after a meal, but continued to remain high; the prefeeding rate was not attained even after $6 \mathrm{~h}$. The average hourly rates calculated are shown on figure 4 . In all groups except those fed the AA diet, the mean rate declined over the course of the experiment. In the AA group, a mean hourly rate of $0.7 \mathrm{mg}$ of $\mathrm{O}_{2} \cdot \mathrm{g}^{-1}$ was found. CAS-fed fish had higher metabolic rates than those fasted or fed the protein-free diet.

The fat-protein ratio in energy terms, calculated with the energy equivalents given by Elliott and Davison (1975), indicates that more fat was used for energy purposes when the PF or AA diets were given than when juvenile carp were fed CAS or were fasted. 


\section{Discussion.}

The relatively poor growth rate with the AA diet compared to the CAS diet has already been observed in carp (Aoe et al., 1970 ; Tanaka et al., 1977) as well as in other teleosts like Tilapia (Mazid et al., 1978) or channel catfish (Wilson et al., 1977). However, the SGR of $2 \%$ with the CAS diet is very poor for juvenile carp weighing $200 \mathrm{mg}$; much higher growth rates were found earlier both with artificial diets and with live food (Bryant and Matty, 1981; Kaushik and Dabrowski, 1983).

The protein digestibility values for the CAS and AA diets were higher than those found in bigger carp (Aoe et al., 1970 ; Plaskas and Katayama, 1981). The latter authors measured digestibility in the posterior portion of the digestive tract and these contents might not represent feces (Austreng, 1978; also see Dabrowski and Dabrowska, 1981). Although some amount of leaching might have occurred under our sampling conditions, the high protein digestibility value for the casein diet compares well with observations by Nose (1967) in young rainbow trout.

The values for the MFN loss found here for juvenile carp $145 \mathrm{mg} \mathrm{N} .100 \mathrm{~g}$ $\operatorname{diet}^{-1}$ ) are lower than those found in bigger carp (144 mg of $\mathrm{N}$ : Ogino et al., 1973) or rainbow trout (Nose, 1967). Under such conditions, it is only natural that true digestibility values do not differ much from apparent digestibility values. Likewise, the sum of MFAA in juvenile carp (183 mg) is lower than that in channel catfish (853 mg: Wilson et al., 1981) or rainbow trout $(634 \mathrm{mg}$ in the final segment of the digestive tract: Dabrowski and Dabrowska, 1981). The latter authors also showed that discrepancies could be great, depending on whether or not traces of dietary nitrogen were taken into account in calculating endogenous loss.

Visual observations of a rapid ingestion rate of the AA diet by juvenile carp is confirmed by the higher filling rate. L-amino acids are known to be gustatory feeding stimulants in several fish (Mackie, 1982). Recent work on juvenile carp of the same batch as ours has shown that L-amino acids are active chemical attractants also in these fish (Saglio and Blanc, in preparation).

Plakas and Katayama (1981) found a slower rate of absorption of amino acids from the casein diet $(4.5 \mathrm{~h})$ compared to those from the amino acid diet $(2.5 \mathrm{~h})$. These authors indicated that AAAD values measured at the same interval after a meal $(2.5 \mathrm{~h})$ were higher for an amino acid diet than for a casinecontaining one. Retention time, calculated on the basis of the time a tracer appareared in the excreta, was also found to be higher with a casein diet (265 min) than with an amino acid $(100 \mathrm{~min})$ diet in carp (Tanaka et al., 1977). Such a twofold increase in the evacuation rate of an amino acid diet is not evident in our experiments. The methodologies were different and the validity of the utilization of $\mathrm{Cr}_{2} \mathrm{O}_{3}$ as a marker in such small fish could be questioned. Although the diets were uniformly marked, it is known that the passage of solid and liquid phases through the digestive tract does not follow the same pattern (Lésel and Sechet, 1982).

Daily ENE losses were affected by the nutritional state of the fish, as 
previously demonstrated by Kaushik and Dabrowski (1983). Comparisons between losses measured by carcass analysis and those measured by ENE indicate wide differences. Fasted carp showed greater loss of carcass nitrogen than could be accounted for by excretory loss, indicating preferential utilization of body protein for energy purposes.

Although the ME values were equally high in all diets compared to data in the literature on bigger salmonids (Cho et al., 1982), energy retention was variable. For almost equivalent energy intakes, the differences in retention between the diets (table 2) emphasize the need for caution when using $\mathrm{ME}$ values in fish, particularly if all forms of nitrogenous catabolites are not quantified. This would also be true of differences observed in nitrogen utilization (table 6).

Dietary amino acids are rapidly absorbed, absorption occurring all along the digestive tract. Plakas et al. (1980) in carp and Yamada et al. (1981a) in rainbow trout observed that postprandial FAA levels reached a maximum earlier with the AA than with the CAS diet. Plakas et al. (1980) also suggested an increase in the rate of amino acid catabolism, judging from a more rapid increase in plasma ammonia levels immediately after feeding the AA diet than when feeding casein. The peak rates of ammonia excretion were also reached earlier in carp fed $A A$ than in those fed CAS. But the total amount excreted was strikingly low in AAfed carp. This raises a question as to the fate of FAA once they are absorbed.

Pequin and Serfaty (1966) found a decrease in ammonia excretion along with a significant increase in amino acid excretion due to L-glutamate injections in carp. Glutamic acid concentration in the blood was also increased. Furthermore, after ingestion of an amino acid diet, plasma glutamine levels were greatly increased in rainbow trout (Yamada et al., 1981a). The action of glutamine synthetase in the formation of glutamine, known to act as a storage form of ammonia, also has to be considered.

Although some branchial and/or urinary excretion of amino acids (Wood, 1958 ; Pequin and Serfaty, 1966) is bound to occur, it cannot possibly account for all the discrepancies. The massive input of FAA across the intestinal barrier is then directed towards organs of rapid amino acid turnover (liver, gill, digestive tract) without any increase in amino acid catabolism or protein synthesis. As the input is great and the turnover rapid, the increased energy demand is satisfied by burning fat, whence the increase in the fat-protein ratio.

In a recent study, Yamada et al. (1981b) showed that increasing the frequency of feeding an AA diet, and thus causing small inputs of amino acids over a period of time, increased the feed efficiency and growth of carp. Murai et al. (1981) used crystalline amino acids coated with casein to decrease the rate of absorption. However, these authors found subsequently that even when they were coated with casein, the amino acids were absorbed as quickly as uncoated ones. The better growth could be attributed only to an improvement in the essential amino acid balance in the tissues.

It was also demonstrated that the oxidative catabolism of amino acids was increased with higher levels of protein in the diet (Zébian and Créach, 1979). With such low rates of ammonia excretion in AA-fed carp, it would be 
hazardous to hypothesize regarding the pathways involved in ammoniogenesis. As shown in bigger carp fed AA (Plakas et al., 1980), while ammonia forms, it may not be detoxified through urea-cycle enzymes, as absolute urea excretion levels are not significantly different between CAS and AA-fed carp.

In higher animals, a massive supply of dietary amino acids creates conditions for orotic aciduria (Hatchwell and Milner, 1978) to deal with excessive quantities of ammonia. Our observations have shown that some orotic acid is also excreted by carp eggs and larvae (unpublished personal results). Further work is necessary on the different nitrogenous metabolites excreted under AA feeding conditions.

Recu en décembre 1982. Accepté en février 1983.

Résumé. Utilisation de l'azote et de l'énergie chez la carpe juvénile (Cyprinus carpio) recevant des régimes à base de caséine, des acides aminés ou un régime protéiprive.

Carpes juvéniles (200 mg PV) ont été nourries avec un régime contenant soit de la caséine (CAS) soit un mélange d'acides aminés (AA) comme source azotée. La croissance, la digestibilité de l'azote et de l'énergie, le transit digestif, l'excrétion azotée et la consommation d'oxygène ont été suivies. Les jeunes carpes recevant le régime AA excrètent beaucoup moins d'ammoniaque comparées à celles nourries du régime CAS. Le métabolisme endogène a également été suivi chez les poissons dans des conditions soit du jeûne, soit d'une alimentation protéiprive (régime PF).

L'azote métabolique fécal est estimé à $45 \mathrm{mg} \mathrm{N} .100 \mathrm{~g}$ d'aliment $\mathrm{sec}^{-1}$. L'excrétion de l'azote endogène est plus élevée chez les poissons à jeun que chez ceux recevant l'aliment non-protéique. La consommation d'oxygène est peu ou pas affectée par le régime alimentaire ; cependant, le rapport entre lipides et protides utilisées à la couverture de besoins énergétiques semble plus élevé chez ceux recevant PF et AA que chez les autres groupes (CAS et jeûne). Les différences, dues aux sources azotées, dans l'utilisation azotée soulignent la nécessité d'une appréciation quantitative de tous les autres catabolites de l'excrétion, en plus de l'ammoniaque et de l'urée.

\section{References}

AOE H., MASUdA I., ABE I., SAITO T., TOYODA T., KITAMURA S., 1970. Nutritive value of protein in young carp. I. Nutritive value of free amino acids. Bull. jap. Soc. sci. Fish., 36, 407-413.

AUSTRENG E., 1978. Digestibility determinations in fish using chromic oxide marking and analysis of contents from different segments of the gastrointestinal tract. Aquaculture, 13, 265-272.

BOLIN D. W., KING R. P., KLOSTERMAN W. W., 1952. A simplified method for the determination of chromic oxide $\left(\mathrm{Cr}_{2} \mathrm{O}_{3}\right)$ when used as an inert substance. Science, 116, 634-635.

BRYANT P. L., MATTY A. J., 1981. Adaptation of carp (Cyprinus carpio) larvae to artificial diets. I. Optimum feeding rate and adaptation age for a commercial diet. Aquaculture, 23, 275286.

CHO C. Y., SLINGER S. J., BAYLEY H. S., 1982. Bioenergetics of salmonid fishes : energy intake, expenditure and productivity. Comp. Biochem. Physiol., 73B, 25-41.

DABROWSKI K., DABROWSKA H., 1981. Digestion of protein by rainbow trout (Salmo gairdneri Rich.) and absorption of amino acids within the alimentary tract. Comp. Biochem. Physiol., 69A, 99-111.

EIFAC, 1971. Salmon and trout feeds and feeding. E.I.F.A.C. Tech. Pap., 12. 
ELLIOTT J. M., DAVISON W., 1975. Energy equivalents of oxygen consumption in animal energetics. Oecologia, 19, 195-201.

HALVER J. E., 1957. Nutrition of salmonoid fishes. IV. An amino acid test diet for chinook salmon. J. Nutr., 62, 245-254.

HATCHWELL L. C., MILNER J. A., 1978. Amino acid-induced orotic aciduria. J. Nutr., 108, $578-584$.

JOBLING M., 1981. Mathematical models of gastric emptying and the estimation of daily rate of food consumption for fish. J. Fish Biol., 19, 245-257.

KAUSHIK S. J., 1979. Application of a biochemical method for the estimation of amino acid needs in fish : quantitative arginine requirements of rainbow trout in different salinities, 197-207. In HALVER J. E., TIEWS K., Proc. World Symp. Finfish nutrition and fishfeed technology, vol. I, Heenemann GmbH, Berlin.

KAUSHIK S. J., DABROWSKI K., 1983. Postprandial metabolic changes in juvenile carp (Cyprinus carpiol. Reprod. Nutr. Dévelop., 23, 223-234.

KAUSHIK S. J., DABROWSKI K., LUQUET P., 1982. Patterns of nitrogen excretion and oxygen consumption during ontogenesis of carp, Cyprinus carpio. Can. J. Fish. Aquat. Sci., 39 , 1095-1105.

LÉSEL R., SECHET J., 1982. Influence d'un stress de manipulation sur le transit de la microflore bactérienne digestive chez la truite arc-en-ciel, Salmo gairdneri Richardson. Acta oecol., OEcol. Applic., 3, 23-33.

LUQUET P., 1971. Efficacité des protéines en relation avec leur taux d'incorporation dans l'alimentation de la truite arc-en-ciel. Ann. Hydrobiol., 2, 175-186.

MACKIE A. M., 1982. Identification of the gustatory feeding stimulants, 275-291. In HARR T. J., Chemoreception in fishes. Elsevier, Amsterdam, Oxford, New York.

MAZID M. A., TANAKA Y., KATAYAMA T., SIMPSON K. L., CHICHESTER C. O., 1978. olism of amino acids in aquatic animals. III. Indispensable amino acids for Tilapia zillii. Bull. jap. Soc. scient. Fish., 44, 739-742.

MITCHELL H. H., 1924. The nutritive value of proteins. Physiol. Rev., 4, 424-478.

MOORE S., SPACKMAN D. H., STEIN H. W., 1958. Chromatography of amino acids on sulfonated polystyrene resins. Analyt. Chem., 30, 1185-1190.

MURAI T., AKIYAMA T., NOSE T., 1981. Use of crystalline amino acids coated with casein in diets for carp. Bi ll. jap. Soc. scient. Fish., 47, 523-527.

MURAI T., AKIYAMA 1. OGATA H., HIRASAWA Y., NOSE T., 1982. Effect of coating amino acids with casein sunnlemented to gelatin diet on plasma free amino acids of carp. Bull. jap. Soc. scient. Fish., 48 i03-710.

NOSE T., 1967. On the metabulic fecal nitrogen in young rainbow trout. Bull. Freshwat. Fish. Res. Lab., 17, 97-105.

NOSE T., 1971. Determination of nutritive value of food protein in fish. III. Nutritive value of casein, whitefish meal and soybean meal in rainbow trout fingerlings. Bull. Freshwat. Fish. Res. Lab., 21, 85-98.

NOSE T., ARAI S., LEE D. L., HASHIMOTO Y., 1974. A note on amino acids essential for growth of young carp. Bull. jap. Soc. scient. Fish., 40, 903-908.

OGINO C., CHEN M.-S., 1973. Protein nutrition in fish. IV. Biological value of dietary proteins in carp. Bull. jap. Soc. scient. Fish., 39, 797-800.

OGINO C., KAKINO J., CHEN M.-S., 1973. Protein nutrition in fish. II. Determination of metabolic fecal nitrogen and endogenous nitrogen excretions of carp. Bull. jap. Soc. scient. Fish., 39, 519-523.

PEQUIN L., SERFATY F., 1966. Acide glutamique et excrétion azotée chez la Carpe commune, Cyprinus carpio L. Comp. Biochem. Physiol., 18, 141-149.

PLAKAS S. M., KATAYAMA T., 1981. Apparent digestibilities of amino acids from three regions of the gastrointestinal tract of carp (Cyprinus carpio) after ingestion of a protein and a corresponding free amino acid diet. Aquaculture, 24, 309-314.

PLAKAS S. M., KATAYAMA T., TANAKA Y., DESHIMARU O., 1980. Changes in the levels of circulating plasma free amino acids of carp (Cyprinus carpio) after feeding a protein and an amino acid diet of similar composition. Aquaculture, 21, 307-322. 
RERAT A., 1971. La valeur biologique des protéines: quelques acquisitions récentes. Ann. Zootech., 20, 193-246.

SAGLIO P., BLANC J. M. Etude comportementale de la réponse aux acides aminés chez le juvénile de carpe, Cyprinus carpio. (In prep.).

SNEDECOR G. W., COCHRAN W. G., 1959. Statistical methods. lowa State Univ. Press, lowa, USA, 534 p.

TANAKA Y., HOKAZONO S., KATAYAMA T., SIMPSON K. L., CHICHESTER C. O., 1977. Metabolism of amino acids in aquatic animals. I. The effect of the addition of phosphate salts, indigestible materials and algae to the diets of carp and the relationship of intestinal retention time to their growth rate. Mem. Fac. Fish. Kagoshima Univ., 26, 39-43.

WILSON R. P., HARDING D. E., GARLING D. L. Jr., 1977. Effect of dietary pH on amino acid utilization and the lysine requirement of fingerling channel catfish. J. Nutr., 107, 166-170.

WILSON R. P., ROBINSON E. H., POE W. E., 1981. Apparent and true availability of amino acids from common feed ingredients for channel catfish. J. Nutr., 111, 923-929.

WOOD J. D., 1958. Nitrogen excretion in some marine teleosts. Can. J. Biochem. Physiol., 36. 1237-1242.

YAMADA S., SIMPSON K. L., TANAKA Y., KATAYAMA T., 1981a. Plasma amino acid changes in rainbow trout Salmo gairdneri force-fed casein and a corresponding amino acid mixture. Bull. jap. Soc. scient. Fish., 47, 1035-1040.

YAMADA S., TANAKA Y., KATAYAMA T., 1981b. Feeding experiments with carp fry fed an amino acid diet by increasing the number of feedings per day. Bull. jap. Soc. scient. Fish., 47, 1247.

ZÉBIAN M. F., CRÉACH Y., 1979. Fraction $\alpha$-aminée libre et dégradation oxydative de quelques acides aminés chez la carpe (Cyprinus carpio L.) : Importance des facteurs nutritionnels, 531544. In HALVER J. E., TIEWS K., Proc. World Symp. Finfish nutrition and fishfeed technology, vol. II, Heenemann $\mathrm{GmbH}$, Berlin. 